\title{
O princípio da autodeterminação dos povos e os direitos humanos das mulheres
}

\author{
Self-determination principle and women \\ human rights
}

George Sarmento Lins Junior ${ }^{1}$

Nycole Lins Gonzaga ${ }^{2}$

\section{RESUMO}

O presente artigo tem por objetivo analisar a possibilidade do direito à autodeterminação dos povos sofrer restrições para que possa ser harmonizado com a proteção dos direitos humanos das mulheres. Parte-se da análise de como se estruturou o princípio da autodeterminação dos povos na prática internacional, sua evolução semântica e interpretativa, tratando também de outros princípios que lhe são correlatos. Em seguida é realizada uma análise sobre os fundamentos de se proteger os direitos humanos das mulheres. Na sequência analisa-se efetivamente a possibilidade do princípio da autodeterminação dos povos sofrer restrições, para então propor medidas necessárias à proteção dos direitos humanos das mulheres. $\mathrm{O}$ estudo se debruça sobre a produção normativa internacional na matéria, que fundamenta o dever de se proteger os direitos humanos das mulheres. Propõe-se assim uma reflexão sob a ótica da teoria dos princípios, da forma como trabalhada por Robert Alexy, como marco teórico principal, mas também com a perspectiva de outros autores, para justificar a possibilidade de se restringir o direito à autodeterminação dos povos, atendendo critérios de razoabilidade e proporcionalidade, em face de violações dos direitos humanos das mulheres.

\section{PALAVRAS-CHAVE} mulheres.

Direitos humanos; princípio da autodeterminação dos povos; direitos humanos das

\begin{abstract}
This article intends to analyze the possibility of the self-determination right suffer restrictions so it can be harmonized with the protection of women human rights. It starts analyzing how self-determination principle has structured itself on the international practice, its semantic and interpretative evolution, dealing with others principles that are its correlatives. Then it is realized an analysis about the fundaments of protect women human rights. In sequence it is effectively analyzed the possibility of the selfdetermination principle suffer restrictions, so it can be proposed necessary measures to

\footnotetext{
1 Doutor em Direito Público/UFPE; pesquisador do Laboratório de Direitos Humanos/UFAL; vice-coordenador do PPGD/UFAL; professor da FDA-UFAL.

2 Bacharela em Direito/UFAL; membro do Laboratório de Direitos Humanos/UFAL; bacharela em Direito/UFAL.
} 
protect women human rights. The study leans over the normative international production on the subject, what fundaments the duty of protect women human rights. Therefore, it is proposed a reflection on the point of view of the principle's theory, in the way it was proposed by Robert Alexy, as the main theoretical framework, but too by the perspective of other authors, to justify the possibility of restrict the self-determination right, attending reasonability and proportionality criteria, in face of women human rights violations.

\section{KEYWORDS}

Human Rights; self-determination principle; women human rights.

\section{INTRODUÇÃO}

A sistemática de proteção internacional dos direitos humanos evoluiu sobremaneira ao longo dos anos. Dentre os vários direitos humanos tutelados, há um complexo de normas voltado especificamente para a proteção dos direitos humanos das mulheres, uma vez que a história da humanidade é marcada pelo desenvolvimento de culturas patriarcais, nas quais as mulheres eram (e na prática ainda são) consideradas inferiores aos homens, sofrendo assim grande discriminação.

Apesar da consagração da igualdade de gênero, e da positivação de vários direitos, a violação de direitos humanos das mulheres ainda é uma temática bastante atual e uma constante realidade em diversos países do mundo. A Organização das Nações Unidas (ONU) estima que cerca de sete a cada dez mulheres ao redor do mundo sofrem violência física ou sexual em algum momento de suas vidas ${ }^{3}$.

A análise da conjuntura em que se insere a questão de gênero, e precisamente das violações de direitos das mulheres, suscita reflexões ao redor das ideologias introjetadas pela cultura patriarcal. Se muitas vezes os direitos das mulheres são violados, mesmo quando consagrados nos diplomas nacionais e internacionais, muito se atribui à cultura da sociedade em questão.

Entretanto, não se pode alegar a prevalência de normas de direito internacional que tutelam a não-intervenção nos Estados, a sua soberania e supremacia, nem tão pouco a prevalência da cultura e do direito interno, para tolerar violações de direitos humanos das mulheres. Até hoje por exemplo, muitos países signatários da Carta da ONU não consideram a pedofilia um crime, ou mesmo a violência doméstica, e muitos punem brandamente o estupro, situações essas que merecem uma intervenção por parte dos organismos internacionais de proteção aos direitos humanos.

É nesse contexto que nos propomos a abordar o princípio da autodeterminação dos povos, noção de Direito Internacional atrelada à formação dos Estados e prevista na Carta da ONU de 1945, que possui ampla dimensão e significado. Consoante o art. $1^{\circ}$ do Pacto Internacional dos Direitos Civis e Políticos (PIDCP) de 1966, em virtude desse direito, os povos "determinam livremente seu estatuto político e asseguram livremente seu desenvolvimento econômico, social e cultural" "

\footnotetext{
3 ONU. UNite Survivor Stories. Vídeo da campanha para o fim da violência contra a mulher. Disponível em: $<$ http://www.un.org/es/women/endviolence/>. Acesso em: 01 out. 2014.

4 BRASIL, Decreto n 592, de 6 de julho de 1992. Promulga o Pacto Internacional sobre Direitos Civis e Políticos. Disponível em: <http://www.planalto.gov.br/ccivil_03/decreto/1990-1994/D0592.htm>. Acesso em: 01 out. 2014.
} 
Trabalharemos com o princípio da autodeterminação dos povos porque este princípio rompe as barreiras territoriais vinculadas à noção de soberania e nãointervenção, princípios que lhe são correlatos. Em suas noções, o elemento territorial perde sua predominância em favor de um elemento pessoal - os cidadãos - que carregam consigo semelhanças que vão além da forma de governo e da economia, mas que carregam principalmente sua identidade cultural, critério último na definição de povo e indissociável da autodeterminação ${ }^{5}$.

Assim, focando nos elementos social e cultural do princípio da autodeterminação dos povos, a discussão que pretendemos fomentar diz respeito até que ponto se pode permitir um livre desenvolvimento social e cultural dos povos. Seria este um direito ilimitado até mesmo nos casos de violações de direitos humanos?

No intuito de relacionar o princípio da autodeterminação dos povos com essa problemática de gênero, pretendemos demonstrar que o princípio da autodeterminação dos povos pode e deve ser restringido quando em conflito com outros importantes direitos, como é o caso dos direitos humanos das mulheres independente de sua etnia, de sua religião e de seus costumes, atentos sem sombra de dúvidas aos limites da razoabilidade e proporcionalidade.

Objetiva-se assim, identificar como o elemento cultural influencia na perpetuação de violações aos direitos humanos das mulheres; definir de que forma o direito à autodeterminação deve ser restringido; destacar a importância dos organismos internacionais no combate a violações de direitos humanos; e, principalmente, enfatizar que medidas devem ser adotadas em casos de violação desses direitos.

\section{O PRINCÍPIO DA AUTODETERMINAÇÃO DOS POVOS}

O princípio da autodeterminação dos povos foi consagrado pela primeira vez no direito internacional na Carta das Nações Unidas de 1945. Entretanto, a expressão autodeterminação já existia, tendo aparentemente surgido nos escritos de filósofos radicais do século XIX na Alemanha, tendo sido também utilizado pelos socialistas, na defesa dos povos oprimidos ${ }^{6}$.

Antes, "a maioria dos juristas ocidentais presumiam ou afirmavam não ter este princípio qualquer conteúdo jurídico, sendo um conceito político moral mal definido"?. Mas a partir de 1945, com os desenvolvimentos trazidos pelas Nações Unidas, a autodeterminação passou a ser considerada um princípio jurídico ${ }^{8}$.

Independentemente das diversas origens epistemológicas, manuais de direito internacional, em geral, associam o termo "autodeterminação dos povos" à natureza "formadora do direito internacional", vinculada à própria história das relações internacionais e da criação dos Estados 9 .

\footnotetext{
${ }^{5}$ BARBOSA, Marco Antonio. Autodeterminação: direito à diferença. São Paulo: Plêiade/Fapesp, 2001, p. 324.

${ }^{6}$ BARBOSA, Marco Antonio. Autodeterminação: direito à diferença. São Paulo: Plêiade/Fapesp, 2001, p. 316.

${ }^{7}$ BROWLIE, lan. Princípios de Direito Internacional Público. Lisboa: Fundação Calouste Gulbekian, 1997, p.618.

8 Ibidem, p.618.

${ }_{9}$ MARCHIONI, Alessandra. O "Princípio da Autodeterminação dos povos" no Direito Internacional e o Contraponto Constitucional do "Princípio do Indigenato". In: Pacto Internacional dos Direitos Econômicos, Sociais e Culturais: da previsão normativa à efetividade no Brasil. Rio de Janeiro: Lumen Juris, 2014, p. 20.
} 
Assim, para a compreensão da evolução do princípio da autodeterminação, é necessária a apreciação do período situado a grosso modo entre 1945 e 1980, no qual toda África, Ásia e Oceania se libertaram do colonialismo, adquirindo plena independência política $^{10}$.

A Carta das Nações Unidas, proclamada em 1945, prevê em seus artigos $1^{\circ}$ e 55 o princípio da autodeterminação:

Artigo 1. Os propósitos das Nações unidas são:

$[\ldots]$

2. Desenvolver relações amistosas entre as nações, baseadas no respeito ao princípio de igualdade de direitos e de autodeterminação dos povos, e tomar outras medidas apropriadas ao fortalecimento da paz universal; $[\ldots]$.

Artigo 55. Com o fim de criar condições de estabilidade e bem-estar, necessárias às relações pacíficas e amistosas entre as Nações, baseadas no respeito ao princípio da igualdade de direitos e da autodeterminação dos povos, as Nações Unidas favorecerão:

a) níveis mais altos de vida, trabalho efetivo e condições de progresso e desenvolvimento econômico e social;

b) a solução dos problemas internacionais econômicos, sociais, sanitários e conexos; a cooperação internacional, de caráter cultural e educacional; e

c) o respeito universal e efetivo dos direitos humanos e das liberdades fundamentais para todos, sem distinção de raça, sexo, língua ou religião ${ }^{11}$.

O direito à autodeterminação não apareceu explícito na Declaração Universal dos Direitos do Homem de 1948, mas em 1960, através da Resolução 1514 da Assembleia Geral da ONU, que aprovou a "Declaração sobre a concessão de independência aos países e aos povos coloniais", a autodeterminação dos povos passou à condição de direito ${ }^{12}$. Logo em seguida a esta Resolução, ainda no ano de 1960, a Assembleia Geral da ONU adotou a resolução 1541 na qual "definiu os critérios segundo os quais se pode considerar que um território não autônomo atingiu a autonomia plena, a saber, o acesso à independência, à livre associação ou à integração num Estado independente"13.

Os Pactos Internacionais de Direitos Humanos de 1966 - Pacto Internacional dos Direitos Civis e Políticos (PIDCP) e Pacto Internacional dos Direitos Econômicos, Sociais e Culturais (PIDESC) - por sua vez, também consagraram o princípio da autodeterminação dos povos, porém de forma mais detalhada. $\mathrm{O}$ art. $1^{\mathrm{o}}$ de ambos os pactos assim dispõe:

\footnotetext{
10 BARBOSA, Marco Antonio. Autodeterminação: direito à diferença. São Paulo: Plêiade/Fapesp, 2001, p. 314. 11 BRASIL, Decreto no 19.841, de 22 de outubro de 1945. Promulga a Carta das Nações Unidas. Disponível em: <http://www.planalto.gov.br/ccivil_03/decreto/1930-1949/d19841.htm>. Acesso em: 02 set. 2014.

12 BARBOSA, Marco Antonio. Autodeterminação: direito à diferença. São Paulo: Plêiade/Fapesp, 2001, p. 316. 13 DESCOLONIZAÇÃO: ONU festeja os 50 anos da Declaração sobre a Concessão de Independência. Disponível em:<http://www.unric.org/pt/actualidade/30115-descolonizacao-onu-festeja-os-50-anos-da-declaracao-sobre-aconcessao-de-independencia>. Acesso em: 02 set. 2014.
} 
1. Todos os povos têm direito à autodeterminação. Em virtude deste direito, determinam livremente o seu estatuto político e asseguram livremente o seu desenvolvimento econômico, social e cultural.

2. Para a consecução de seus objetivos, todos os povos podem dispor livremente das suas riquezas e dos seus recursos naturais, sem prejuízo das obrigações decorrentes da cooperação econômica internacional, baseada no princípio do proveito mútuo do Direito Internacional. Em caso algum poderá um povo ser privado dos seus próprios meios de subsistência.

3. Os Estados Partes no presente Pacto, inclusive aqueles que tenham a responsabilidade de administrar territórios não autônomos e territórios sob tutela, deverão promover o exercício do direito à autodeterminação e respeitar esse direito, em conformidade com as disposições da Carta das Nações Unidas ${ }^{14}$. (Grifo nosso)

Em 1970, a Assembleia Geral da ONU tratou novamente da autodeterminação dos povos na "Declaração sobre os Princípios de Direito Internacional Relativos às Relações Amigáveis", Resolução 2.625/70, reafirmando a preocupação com a secessão de grupos minoritários e separatistas em face de Estados soberanos, que extrapolassem a situação dos povos coloniais ${ }^{15}$.

O que se pode observar destes diplomas internacionais é que o princípio da autodeterminação dos povos "acompanhou os movimentos de um processo histórico de formação dos Estados" "16. Seu conteúdo e alcance estiveram sempre ligados aos interesses políticos daqueles que o invocavam ou o procuravam restringir.

Daniel Thürer, numa interessante análise da evolução do princípio da autodeterminação dos povos, afirma que seu conteúdo e significado legal, só podem ser entendidos de acordo com as forças políticas e ideológicas que lhe produziram, e assim, divide o princípio em quatro fases de desenvolvimento ${ }^{17}$.

Na primeira fase tem-se o direito à autodeterminação "democrático", entendido a seu tempo como o direito de todas as pessoas de decidir seu próprio destino, ideia trazida do Iluminismo e evidente na Declaração de Independência Americana, de 1776. Na segunda, tem-se o direito de autodeterminação "nacional", advindo do nacionalismo emergente do século XIX, que deu à autodeterminação uma forma mais precisa, uma vez que deslocou o centro do princípio das pessoas vistas individualmente, para focar nas pessoas enquanto partes de uma nação, como entidade étnica e cultural ${ }^{18}$.

A terceira fase de desenvolvimento é a do direito à autodeterminação "socialista", inserido no contexto da Revolução de 1917, no qual esse direito foi elevado a um princípio geral de direito internacional, no intuito de fortalecer e expandir o comunismo. Por fim, a quarta fase seria do direito à autodeterminação "colonial", conceito que apareceu após a Segunda Guerra Mundial, no contexto da descolonização, de aplicação

\footnotetext{
14 BRASIL, Decreto n 592, de 6 de julho de 1992. Promulga o Pacto Internacional sobre Direitos Civis e Políticos. Disponível em: <http://www.planalto.gov.br/ccivil_03/decreto/1990-1994/D0592.htm>. Acesso em: 01 out. 2014.

15 MARCHIONI, Alessandra. O "Princípio da Autodeterminação dos povos" no Direito Internacional e o Contraponto Constitucional do "Princípio do Indigenato". In: Pacto Internacional dos Direitos Econômicos, Sociais e Culturais: da previsão normativa à efetividade no Brasil. Rio de Janeiro: Lumen Juris, 2014, p. 26.

16 Ibidem, p. 21.

17 THÜRER, Daniel. The Right of Self-determination of peoples. In: Law and State. Institute for Scientific Co-operation, v. 35 , jan. 1987, p. 23.

18 Ibidem, p. 24.
} 
geográfica limitada aos impérios coloniais europeus, dando lugar a uma concepção emancipatória ${ }^{19}$.

Atualmente, porém, o princípio da autodeterminação dos povos ganha novos contornos, uma vez que continua a se inserir na realidade sociopolítica pelo canal das reivindicações dos povos em luta. Assim, vem sendo utilizado sob uma perspectiva interna, reivindicado por povos indígenas ou minorias étnicas na luta pela autodeterminação dentro dos Estados que habitam.

Quando da redação da Carta da ONU, "a autodeterminação constituía um mero ideal prometido ao respeito pelos Estados membros" ${ }^{20}$, com base no interesse da paz e da estabilidade entre Estados. Já no meio do século XX, como a ONU foi dominada pelos países de Terceiro Mundo e pelos países socialistas, a autodeterminação passou a ter a função legitimadora da liberação dos povos que estavam submetidos ao colonialismo de ultramar $^{21}$.

Por analogia, esse direito foi ainda utilizado para opor-se ao racismo branco na África do Sul e à dominação estrangeira no caso dos israelenses e palestinos ${ }^{22}$. Nesses casos, observa-se o direito de liberação de uma opressão externa.

Entretanto, os países centrais do ocidente vieram a sugerir um acréscimo na abrangência da autodeterminação, através de uma perspectiva interna ou extracolonial, a fim de permitir que povos oprimidos por regimes políticos no Terceiro Mundo ou nos regimes socialistas pudessem se liberar da opressão interna ${ }^{23}$.

Assim, segundo Alessandra Marchioni,

[...] o princípio da autodeterminação dos povos variou em significado de "direito positivo incontestável dos povos à independência, à autonomia e à secessão territorial" para, na contemporaneidade, ser identificado como uma norma internacional de "valor relativo" sujeita a uma determinação política em âmbito interno ${ }^{24}$.

Segundo Marco Antonio Barbosa, "o que mais importa no conteúdo da autodeterminação é o direito de escolher em que ele implica; além disso, trata-se de uma norma imperativa de direito internacional geral, e que não pode ser derrogada por nenhuma outra" 25 .

No presente trabalho, propõe-se uma análise do princípio da autodeterminação dos povos sob uma nova perspectiva. Para além de uma conjuntura meramente política, pretende-se visualizar essa norma internacional como legitimadora do direito de todos os povos de fazerem suas próprias escolhas, seja no âmbito político, econômico, social, cultural, levantando assim uma crítica aos limites dessa autodeterminação nos casos de violações dos direitos humanos das mulheres.

Portanto, é preciso atentar para o fato de que, apesar de muitas vezes atrelado apenas ao contexto da descolonização, tendo assim seu significado legal limitado à

\footnotetext{
19 Ibidem, p. 24-25.

20 BARBOSA, Marco Antonio. Autodeterminação: direito à diferença. São Paulo: Plêiade/Fapesp, 2001, p. 334.

21 BARBOSA, Marco Antonio. Autodeterminação: direito à diferença. São Paulo: Plêiade/Fapesp, 2001, p. 334.

22 Ibidem, p. 334.

23 Ibidem, p. 334-335.

24 MARCHIONI, Alessandra. O "Princípio da Autodeterminação dos povos" no Direito Internacional e o Contraponto Constitucional do "Princípio do Indigenato". In: Pacto Internacional dos Direitos Econômicos, Sociais e Culturais: da previsão normativa à efetividade no Brasil. Rio de Janeiro: Lumen Juris, 2014, p. 22.

25 BARBOSA, Marco Antonio. Autodeterminação: direito à diferença. São Paulo: Plêiade/Fapesp, 2001, p. 318.
} 
dissolução dos impérios coloniais europeus, o princípio da autodeterminação dos povos é muito mais abrangente.

Seu alcance não se restringe aos povos submetidos à colonização, ou a minorias étnicas, ou ainda aos povos indígenas, mas como afirma Marchioni, ao tratar do $\S 1^{\circ}$, art. $1^{\circ}$ do PIDESC, "esse princípio de direito positivo abrange 'todos os povos', não apenas os povos submetidos à colonização", e acrescenta que o princípio deve "ser aplicado de forma universal, para além de uma interpretação histórica associada ao contexto da descolonização" 26 .

Ademais, outro ponto importante para essa nova abordagem do princípio é resgatar o amplo conceito da autodeterminação previsto nos Pactos de 1966, que vai além da sua ótica política e econômica.

Como preconiza o art. $1^{\circ}, \S 1^{\circ}$ do PIDESC, em virtude do direito à autodeterminação, todos os povos "determinam livremente o seu estatuto político e asseguram livremente o seu desenvolvimento econômico, social e cultural"27.

As dimensões social e cultural desse direito são geralmente esquecidas, o que não deve acontecer uma vez que não pode haver real autodeterminação sem também o respeito à identidade cultural.

Identidade cultural e autodeterminação são indissociáveis. A identidade cultural é o critério último na definição de povo, sujeito ativo do direito à autodeterminação e desencadeia, consequentemente, o processo de autodeterminação. Apenas a autodeterminação pode ser o instrumento adequado para proteger a identidade cultural dos povos e, por conseguinte garantir o direito a diferença ${ }^{28}$.

Ressaltamos aqui as dimensões social e cultural do princípio da autodeterminação dos povos porque estes elementos vinculam os indivíduos de uma sociedade para além de um Estado territorialmente constituído, garantindo que qualquer sociedade, qualquer etnia, possa desenvolver-se de acordo com seus costumes. Ademais, a legitimidade do poder está no povo, e não no Estado, que age enquanto mandatário daquele ${ }^{29}$.

Assim, princípios como a soberania e a não-intervenção se tornam de pequeno alcance diante da discussão que pretendemos fomentar: até que ponto se pode permitir um livre desenvolvimento social e cultural dos povos? Seria este um direito ilimitado até mesmo nos casos de violações de direitos humanos pelo seu caráter de norma cogente? $\mathrm{E}$ no caso das violações de direitos humanos das mulheres, estas não merecem tutela porque a sociedade onde vivem é que decide como se autodeterminar?

Apresentar o princípio da autodeterminação dos povos sob essa nova ótica, de início, pode parecer "remar contra a maré", uma vez que é um direito invocado nas lutas sociais de povos oprimidos. Entretanto, se algumas minorias étnicas ainda não atingiram o status de se autodeterminarem, por outro lado tem-se os demais povos de um contexto mundial que gozam desse direito, o que suscita uma preocupação em restringi-lo.

${ }^{26}$ MARCHIONI, Alessandra. O "Princípio da Autodeterminação dos povos" no Direito Internacional e o Contraponto Constitucional do "Princípio do Indigenato". In: Pacto Internacional dos Direitos Econômicos, Sociais e Culturais: da previsão normativa à efetividade no Brasil. Rio de Janeiro: Lumen Juris, 2014, p. 25.

27 BRASIL, Decreto n 591, de 6 de julho de 1992. Promulga o Pacto Internacional sobre os Direitos Econômicos, Sociais e Culturais. Disponível em: <http://www.planalto.gov.br/ccivil_03/decreto/1990-1994/D0591.htm>. Acesso em: 01 set. 2014.

28 BARBOSA, Marco Antonio. Autodeterminação: direito à diferença. São Paulo: Plêiade/Fapesp, 2001, p. 324.

29 Ibidem, p. 315. 
Ao levantar um discurso em prol dos direitos humanos das mulheres, contrapondo-o ao princípio da autodeterminação, não nos apartamos da consciência de que sem esse princípio os direitos humanos dos povos oprimidos também estão sendo violados.

Nos termos do art. 55 da Carta da ONU de 1945, é papel das Nações Unidas, através do respeito ao princípio da igualdade de direitos e da autodeterminação dos povos, favorecer o "respeito universal e efetivo dos direitos humanos e das liberdades fundamentais para todos, sem distinção de raça, sexo, língua ou religião".

Se alguns doutrinadores afirmam que o princípio da autodeterminação dos povos é meio de se garantir direitos humanos, outros vão mais além, enquadrando-o também como sendo um direito humano. A esse respeito, trataremos mais adiante ao analisarmos a natureza jurídica do princípio da autodeterminação dos povos.

Entretanto, deve-se ter em mente que é preciso encontrar um equilíbrio entre a demanda pela autodeterminação dos povos, em todas as suas dimensões, e a proteção de outros direitos humanos que podem vir a ser violados, como é o caso dos direitos das mulheres.

Após essa apresentação do princípio da autodeterminação dos povos, necessário se faz analisar outros princípios de direito internacional que lhe são correlatos, como é o caso do princípio da soberania e do princípio da não-intervenção, ao passo que já foram mais explorados no contexto da relativização em prol dos direitos humanos.

\section{PRINCÍPIO DA SOBERANIA E DA NÃO-INTERVENÇÃO}

Soberania e não-intervenção são temáticas bastante exploradas no bojo das noções de direito internacional. Atreladas à formação dos Estados e necessárias para a afirmação de poder e autoridade, essas noções são de extrema importância para a discussão que se pretende fomentar no tocante à relação entre a ordem interna de cada Estado e a ordem internacional.

Com relação à soberania, esta aparece em sentido restrito, ou seja, com significado preciso, apenas no século XVI. Teria surgido junto à noção de Estado, para qualificá-lo como sujeito único e exclusivo das relaçõ̃es de poder ${ }^{30}$.

Como explica Hermann, a formação do Estado moderno seria o resultado de uma centralização, para fazer frente de um lado à organização medieval e de outro às pretensões universalistas do papado e do império ${ }^{31}$.

Essas oposições evidenciam assim a dupla face, interna e externa da soberania estatal, pois considera-se que "o Estado soberano detém internamente supremacia absoluta e externamente encontra-se em posição de igualdade com relação aos demais soberanos, uma vez que não se reconhece nenhuma instância superior à qual deva obediência" ${ }^{32}$.

O desenvolvimento do conceito de soberania está intimamente ligado ao surgimento e à evolução do Estado. Vários filósofos desenvolveram estudos ligados ao Estado e à afirmação de seu poder soberano, conceituando a soberania, como Maquiavel, Bodin, Hobbes, Grocio, dentre tantos outros.

\footnotetext{
30 HERMANN, Breno. Soberania, não intervenção e não indiferença: reflexões sobre o discurso diplomático brasileiro. Brasília: Fundação Alexandre de Gusmão, 2011, p. 32.

31 Ibidem, p. 32.

32 Ibidem, p. 32.
} 
Entretanto, as acepções atuais do termo soberania sofreram alterações em relação a suas origens, em virtude da constante mudança na mente humana, no contexto históricopolítico em que se encontra a sociedade e, principalmente, na forma como se dispõem as relações internacionais.

A Paz de Westfália (1648-1659) foi o primeiro texto normativo intergovernamental a reconhecer o princípio da soberania nacional, colocando-o no topo da estrutura mundial da época. Trouxe regras como a igualdade soberana entre os Estados, respeito ao território, aos limites internacionais e a não-intervenção em assuntos internos de outros Estados ${ }^{33}$. Entretanto foi com o advento da Revolução Francesa que se consolidou a ideia de soberania, que deixou de lado a antiga ordem medieval para dar lugar à perspectiva moderna ${ }^{34}$.

A soberania é atributo fundamental do Estado, pois não lhe basta encontrar-se sobre certo território bem delimitado, com uma população estável e sujeita à autoridade de um governo ${ }^{35}$. É necessária a soberania, que faz do Estado "titular de competências que, precisamente porque existe uma ordem jurídica internacional, não são ilimitadas, mas nenhuma outra entidade as possui superiores" 36 .

Atualmente, é inegável que a noção de soberania está sendo intensamente afetada pela globalização, que "influencia a maneira como o Estado executa suas prerrogativas exclusivas" 37 .

Breno Hermann menciona, assim, alguns desafios que a noção de soberania estatal enfrenta atualmente. A globalização é o primeiro deles, com o fluxo crescente de bens, pessoas, capitais, a diminuição das distâncias geográficas, das fronteiras nacionais, a troca de influências políticas, econômicas e culturais. Com isso, os contornos exatos do exercício do poder tornaram-se menos claros $^{38}$.

As intervenções humanitárias, feitas por parte da comunidade internacional, colocam-se como mais um desafio à soberania, na medida em que a preocupação com o bem-estar e a garantia dos direitos humanos dos cidadãos ganhou proporções globais, suscitando questionamentos quanto à soberania ilimitada dos Estados violadores dos direitos humanos de seus cidadãos ${ }^{39}$.

Nesse contexto, com o surgimento de diversos organismos internacionais e um crescimento do ativismo político para além do espaço de ação do Estado, esse deixa "de ser o único centro de gravidade em torno do qual se desenrola a atividade política" ${ }^{40}$, rompendo mais uma vez as barreiras da soberania estatal.

Surgem também regimes internacionais patrocinados por entidades como a ONU e instituições supranacionais como a União Europeia, estabelecendo novas formas de governança que podem limitar a liberdade do Estado em certas questões ${ }^{41}$.

\footnotetext{
33 TAIAR, Rogério. Direito Internacional dos Direitos Humanos: Uma discussão sobre a relativização da soberania face à efetivação da proteção internacional dos direitos humanos. 2009. $321 \mathrm{f}$. Tese (Doutorado em Direitos Humanos) - Faculdade de Direito, Universidade de São Paulo, São Paulo. 2009, p. 70.

34 Ibidem, p. 71.

35 REZEK, Francisco. Direito Internacional Público. 13ª ed. São Paulo: Saraiva, 2011, p. 259.

36 Ibidem, p. 259.

${ }^{37}$ HERMANN, Breno. Soberania, não intervenção e não indiferença: reflexões sobre o discurso diplomático brasileiro. Brasília: Fundação Alexandre de Gusmão, 2011, p. 97.

$38 \mathrm{lbidem}$, p. 99.

39 Ibidem, p. 99.

40 Ibidem, p. 100.

41 Ibidem, p. 100.
} 
Observa ainda o autor, como obstáculo à soberania, a emergência do chamado "direito cosmopolita", que se refere às normas jurídicas que estabelecem prerrogativas e limitações, direitos e obrigações aos Estados e atuam para além da esfera nacional ${ }^{42}$.

Por fim, segundo o autor, as lutas de populações indígenas em nome de sua autodeterminação, proporcionam uma crítica à noção tradicional de soberania estatal, uma vez que o Estado não é capaz de acomodar todas essas reivindicações ${ }^{43}$.

Aqui abrimos um parêntese para chamar atenção ao fato de que, se muitas vezes o princípio da autodeterminação dos povos - foco do presente trabalho - parece contrapor-se à noção de soberania estatal, por entrarem em choque os interesses de minorias e os interesses do Estado, em verdade essas noções são correlatas. Um Estado soberano é capaz de autodeterminar-se, e para além da noção de Estado, outros povos, sejam indígenas, sejam outras minorias étnicas, também buscam o direito de se autodeterminar.

Assim também destaca-se o princípio da não-intervenção, que a partir de 1648 tornou-se regra básica de coexistência entre os Estados. Corolário da soberania estatal, parte da noção de que as relações internacionais se estabelecem, via de regra, em torno de Estados autônomos e autossuficientes ${ }^{44}$.

Parte-se da premissa de que todos os Estados são iguais na ordem internacional e assim não seriam toleradas intervenções em sua ordem interna, pois através da soberania compete a cada Estado o exercício do poder sobre seus domínios.

Através dos instrumentos internacionais que asseguram a não-intervenção, os Estados firmaram um compromisso de não se imiscuir nos assuntos internos uns dos outros. Entretanto, a nova ordem internacional, após as atrocidades cometidas na Segunda Guerra Mundial, passou a se preocupar com a proteção dos direitos humanos, "redefiniase, desse modo, a noção de soberania absoluta do Estado, que passava a incorporar em seu conceito compromissos e obrigações de alcance internacional no que diz respeito aos direitos humanos" 45 .

A soberania, apesar de conferir autonomia e independência aos Estados, não justifica que estes possam atuar da forma como bem entendam na ordem internacional, pois possuem o dever de respeitar os direitos humanos de cada indivíduo ${ }^{46}$.

Contudo isso não significa que o princípio da soberania deva ser substituído pelo princípio da proteção da dignidade humana, uma vez que são princípios jurídicos complementares e não excludentes ${ }^{47}$.

Os Estados soberanos, no intuito de assegurar que o sistema internacional funcione dentro de uma mínima ordem necessária à convivência harmoniosa, submetemse a aceitar e respeitar as leis internacionais, com isso, "não deixam de ser soberanos, pois mantêm suas competências, mas tal soberania é limitada pelo direito internacional" 48 .

O exercício da soberania pelo Estado, na forma como se concebe atualmente o Estado Democrático de Direito, é indissociável da promoção do bem de todos e

\footnotetext{
42 Ibidem, p. 101.

43 Ibidem, p. 101.

44 AMARAL JÚNIOR, Alberto do. Curso de Direito Internacional Público. $4^{\text {a }}$ ed. São Paulo: Atlas, 2013, p. 224.

45 PIOVESAN, Flávia. Direitos Humanos e o Direito Constitucional Internacional. $19^{a}$ ed. São Paulo: Saraiva, 2009, p. 115.

46 TAIAR, Rogério. Direito Internacional dos Direitos Humanos: Uma discussão sobre a relativização da soberania face à efetivação da proteção internacional dos direitos humanos. 2009. $321 \mathrm{f}$. Tese (Doutorado em Direitos Humanos) - Faculdade de Direito, Universidade de São Paulo, São Paulo. 2009, p. 255.

47 Ibidem, p. 254.

48 Ibidem, p. 255.
} 
consequentemente da proteção dos direitos humanos. Assim, o princípio da dignidade humana "não diminui a soberania dos Estados, mas ao contrário, reafirma seu conceito enquanto manifestação do poder estatal limitado pelo direito"49.

Atentos a essa crescente preocupação com a proteção dos direitos humanos, que tomou proporções globais e influenciou até mesmo noções básicas de direito internacional como o princípio da soberania e da não-intervenção, passamos a analisar de onde se extrai o fundamento do dever de se garantir e efetivar a proteção dos direitos humanos das mulheres.

\section{FUNDAMENTOS DO DEVER DE PROTEGER OS DIREITOS HUMANOS DAS MULHERES}

O processo de universalização dos direitos humanos propiciou a formação de um sistema normativo internacional de proteção, que é fundamento de existência e validade do sistema nacional de proteção dos direitos humanos, e com este interage.

Assim, consoante Stela Cavalcanti, "criadas por meio de tratados, convenções ou pactos, as normas de direito internacional obrigam os Estados a promover medidas necessárias para torná-las executórias no plano do direito interno"50.

Ao nos debruçarmos sob a análise da legitimidade de intervenções nos casos de violação dos direitos humanos das mulheres, devemos ter em mente que seu fundamento pode ser extraído do sistema internacional de proteção de tais direitos, e também, das próprias normas gerais que regulam o direito internacional.

Grande parte das normas internacionais existentes tiveram origem na celebração de tratados e convenções entre os Estados. Se num primeiro momento os tratados eram exclusivamente bilaterais, a partir do século XIX passaram a surgir tratados multilaterais, firmando compromissos entre vários Estados de importância decisiva na regulação da vida internacional ${ }^{51}$.

Até meados do século XX, o direito dos tratados tinha natureza consuetudinária, vindo a ser codificado apenas em 1969, após a elaboração pela Comissão de Direito Internacional da ONU da Convenção de Viena sobre o Direito dos Tratados. Até então predominava o princípio da boa-fé e o princípio pacta sunt servanda para recomendar o cumprimento fiel das obrigações avençadas ${ }^{52}$.

Com a Convenção de Viena de 1969, restou positivado o princípio pacta sunt servanda, que segundo seu art. 26, prevê que "todo tratado em vigor obriga as partes e deve ser cumprido por elas de boa fé" 53 .

Os tratados que consagram a proteção dos direitos humanos possuem a marca do consenso e da convergência de interesses, vinculando os Estados à cláusula pacta sunt

\footnotetext{
49 Ibidem, p. 255.

50 CAVALCANTI, Stela Valéria Soares de Farias. Violência Doméstica Contra a Mulher no Brasil. $4^{a}$ Ed. Salvador: Jus Podivm, 2012, p. 94.

51 AMARAL JÚNIOR, Alberto do. Curso de Direito Internacional Público. $4^{\text {a }}$ ed. São Paulo: Atlas, 2013, p. 47-48.

52 Ibidem, p. 48.

53 BRASIL, Decreto $n^{0} 7.030$, de 14 de dezembro de 2009. Promulga a Convenção de Viena sobre o Direito dos Tratados. Disponível em: <http://www.planalto.gov.br/ccivil_03/_Ato2007-2010/2009/Decreto/D7030.htm>. Acesso em: 15 set. 2014.
} 
servanda ${ }^{54}$. Assim, os países signatários de tratados que consagram a igualdade de gênero e a proteção dos direitos humanos das mulheres, ao violá-los estão sujeitos à responsabilização, uma vez que se comprometeram a cumprir as obrigações pactuadas.

A Carta da ONU de 1945, que consolida o movimento de internacionalização dos direitos humanos, busca desde seu preâmbulo reafirmar a fé na igualdade de direitos entre homens e mulheres.

No artigo $1^{\circ}$ de sua Carta, a ONU consagra dentre seus propósitos:

3. Conseguir uma cooperação internacional para resolver os problemas internacionais de caráter econômico, social, cultural ou humanitário, e para promover e estimular o respeito aos direitos humanos e às liberdades fundamentais para todos, sem distinção de raça, sexo, língua ou religião ${ }^{55}$. (Grifo nosso)

A ONU possui atualmente 193 países-membros ${ }^{56}$, muitos destes violadores de direitos humanos das mulheres. Entretanto, observa-se que sua Carta consagra a igualdade de gênero e o respeito aos direitos humanos e às liberdades fundamentais para todos, sem distinção de sexo. Assim, os países-membros estão obrigados a promover todas as medidas normativas e administrativas para honrar o compromisso firmado no plano internacional.

Os instrumentos internacionais específicos de proteção aos direitos das mulheres também legitimam intervenções nos casos de violação. Nesse sentido, temos instrumentos firmados tanto no sistema global de proteção dos direitos humanos quanto nos sistemas regionais, como já explicitado anteriormente.

Por sua vez, a Convenção sobre a Eliminação de Todas as Formas de Discriminação contra a Mulher, editada pela ONU em 1979, como primeiro instrumento específico de proteção dos direitos das mulheres, consagra o compromisso dos Estadosmembros no combate à discriminação contra a mulher e na promoção de medidas afirmativas para efetivar seus direitos. Destacamos seu artigo $3^{\circ}$, que assim prevê:

Art. $3^{\circ}$ - Os Estados Partes tomarão, em todos os campos e, em particular, no político, social, econômico e cultural, todas as medidas apropriadas, inclusive de caráter legislativo, para assegurar o pleno desenvolvimento e o progresso das mulheres, com vistas a garantir-lhes o exercício e gozo dos direitos humanos e das liberdades fundamentais em igualdade de condições com o homem ${ }^{57}$.

A Convenção vai além, ao prever em seu art. $5^{\circ}$, a, que os Estados-membros devem inclusive adotar medidas para modificar os esquemas e padrões de comportamento sociocultural de homens e mulheres, a fim de eliminar os preconceitos e práticas

54 SARMENTO, George. Pontes de Miranda e a Teoria dos Direitos Fundamentais. Disponível em: $<$ <ttp://www.georgesarmento.com.br/wp-content/uploads/2011/02/Pontes-de-Miranda-e-a-teoria-dos-direitosfundamentais2.pdf>. Acesso em: 15 out. 2014, p. 03.

${ }^{5}$ BRASIL, Decreto $n^{0}$ 19.841, de 22 de outubro de 1945. Promulga a Carta das Nações Unidas. Disponível em: $<$ <ttp://www.planalto.gov.br/ccivil_03/decreto/1930-1949/d19841.htm>. Acesso em: 02 set. 2014.

${ }^{56}$ PAÍSES-MEMBROS. Disponivel em: <http://www.onu.org.br/conheca-a-onu/paises-membros/>. Acesso em: 11 out. 2014.

${ }^{57}$ BRASIL, Decreto n ${ }^{0} 4.377$, de 13 de setembro de 2002. Promulga a Convenção sobre a Eliminação de Todas as Formas de Discriminação contra a Mulher. Disponível em: http://www.planalto.gov.br/ccivil_03/decreto/2002/D4377.htm>. Acesso em: 06 ago. 2014. 
consuetudinárias, ou de qualquer outro tipo, que estejam baseados na ideia de inferioridade ou superioridade de qualquer dos $\operatorname{sexos}^{58}$.

Assim, os direitos humanos das mulheres estão acima de práticas, costumes e culturas preconceituosas e discriminadoras, o que faz de sua proteção compromisso dos Estados-membros da Convenção.

A Declaração sobre a Eliminação da Violência contra a Mulher, de 1993, ao abordar especificamente a questão da violência contra a mulher, visa complementar a Convenção sobre a Eliminação de Todas as Formas de Discriminação contra a Mulher. Tal instrumento expande e especifica o rol de direitos das mulheres a nível global.

Com relação à Convenção Interamericana para Prevenir, Punir e Erradicar a Violência contra a Mulher, de 1994, instrumento de proteção em nível regional, podemos destacar seu art. $4^{\circ}$ que trata do direito de toda mulher a ter reconhecidos e protegidos todos os direitos humanos e liberdades previstos nos instrumentos regionais e internacionais de direitos humanos ${ }^{59}$. É dever dos Estados proteger tais direitos, que são básicos para que qualquer mulher viva com um mínimo de dignidade.

No ordenamento jurídico internacional não faltam instrumentos de tutela aos direitos humanos das mulheres.

Após a análise do princípio da autodeterminação dos povos e seus corolários, os princípios da soberania e da não-intervenção, esse panorama geral do sistema internacional de proteção dos direitos humanos nos proporciona uma base sólida para justificar a necessidade de ação nos países violadores de direitos humanos das mulheres, delineando assim a possibilidade de se restringir o princípio da autodeterminação dos povos, como veremos a seguir.

\footnotetext{
58 Art. $5^{\circ}$ - Os Estados Partes tomarão todas as medidas apropriadas para:

a) modificar os esquemas e padrões de comportamento sócio-cultural de homens e mulheres, com vistas a alcançar a eliminação dos preconceitos e práticas consuetudinárias, ou de qualquer outro tipo, que estejam baseados na ideia de inferioridade ou superioridade de qualquer dos sexos ou em papéis estereotipados de homens e mulheres;

b) assegurar que a educação familiar venha a contribuir para um entendimento adequado da maternidade como função social e para o reconhecimento da responsabilidade comum de homens e mulheres no que diz respeito à educação e ao desenvolvimento dos seus filhos, entendendo-se que o interesse dos filhos é consideração primordial em todos os casos.

59 Art. $4^{0}$ - Toda mulher tem direito ao reconhecimento, desfrute, exercício e proteção de todos os direitos humanos e liberdades consagrados em todos os instrumentos regionais e internacionais relativos aos direitos humanos. Estes direitos abrangem, entre outros:

a. direito a que se respeite sua vida;

b. direito a que se respeite sua integridade física, mental e moral;

c. direito à liberdade e à segurança pessoais;

d. direito a não ser submetida a tortura;

e. direito a que se respeite a dignidade inerente à sua pessoa e a que se proteja sua família;

f. direito a igual proteção perante a lei e da lei;

g. direito a recurso simples e rápido perante tribunal competente que a proteja contra atos que violem seus direitos;

h. direito de livre associação;

i. direito à liberdade de professar a própria religião e as próprias crenças, de acordo com a lei; e

j. direito a ter igualdade de acesso às funções públicas de seu país e a participar nos assuntos públicos, inclusive na tomada de decisões.
} 


\section{A NATUREZA JURÍDICA DO PRINCÍPIO DA AUTODETERMINAÇÃO DOS POVOS}

Vimos anteriormente, em linhas gerais, como se estruturou o princípio da autodeterminação dos povos na prática internacional, sua evolução semântica e interpretativa, buscando trazê-lo para o centro do debate que estamos fomentando.

Pelo que foi exposto, podemos perceber que esse princípio até hoje é bastante indeterminado, tanto em termos de escopo quanto em termos de conteúdo. Vale então ressaltar que quando uma norma é editada em termos vagos espera-se que ao longo do tempo um significado mais determinado seja desenvolvido ${ }^{60}$.

Entretanto, não foi isso o que aconteceu com o princípio da autodeterminação dos povos, pois os Estados, seus principais atores, raramente editam normas ou manifestam opiniões para clarificar o conteúdo desse princípio, uma vez que se beneficiam dessa indeterminação para não terem seus interesses contrariados ${ }^{61}$.

Os Estados evitam a determinação semântica do princípio por temerem suas consequências, tendo em vista que se trata de um princípio de elevada importância política em nível internacional.

Apesar da pequena bibliografia a respeito e de uma série de abordagens superficiais acerca desse princípio, para aprofundar o debate que gira em torno do nosso tema é preciso definir claramente a natureza jurídica então defendida do princípio da autodeterminação dos povos. Superada a questão da dicotomia princípio político ou norma legal, posto que se encontra positivado em alguns instrumentos internacionais, passamos a apreciação de seu enquadramento como direito humano.

Nesse sentido, tendo em vista a normatização do princípio da autodeterminação dos povos no sistema jurídico internacional é possível afirmar que este se articula como direito humano previsto em diversos tratados.

Em 1966, com os dois Pactos ${ }^{62}$ de direitos humanos, a autodeterminação dos povos foi articulada como um direito humano em instrumentos da ONU. Assim, para Mathew Saul, apesar das críticas à caracterização desse princípio como um direito humano, isso está longe de ser polêmico, por uma questão de doutrina jurídica internacional $^{63}$.

Consoante Saul, a aceitação da autodeterminação dos povos como direito humano traz consequências para a natureza da norma, tendo em vista que esta tem que se adequar à moldura dos direitos humanos, obedecendo assim regras-chave para o seu desenvolvimento ${ }^{64}$.

Sendo um direito humano não absoluto, a autodeterminação dos povos sujeita-se a limitações. Como afirma Matthew Saul, seu exercício deve ser balanceado com os outros direitos humanos, como liberdade de expressão e liberdade de religião ${ }^{65}-$ e no presente caso, com os direitos humanos das mulheres.

\footnotetext{
60 SAUL, Matthew. The Normative Status of Self-Determination in International Law: A Formula for Uncertainty in the Scope and Content of the Right? Disponivel em: <http://papers.ssrn.com/sol3/papers.cfm?abstract_id=1881679>. Acesso em: 10 out. 2014, p. 02.

61 Ibidem, p. 02.

62 Pacto Internacional dos Direitos Civis e Políticos e Pacto Internacional dos Direitos Econômicos Sociais e Culturais, ambos de 1966.

63 Ibidem, p. 14.

64 Ibidem, p. 14.

65 Ibidem, p. 15.
} 
Além dessa análise do princípio da autodeterminação dos povos sob uma perspectiva de direito humano, o autor norte-americano levanta também considerações acerca da relação entre a autodeterminação e as noções de soberania e não-intervenção, que lhe são correlatas.

Com relação à soberania, para além de um contexto colonial, o direito à autodeterminação fornece uma base para a chamada soberania popular, por meio da qual a população de um Estado como um todo possui o direito de determinar livremente seu status político e promover seu desenvolvimento econômico, social e cultural, noção que vai além de um efetivo controle territorial ${ }^{66}$.

Já com relação à não-intervenção, muitos autores sugerem que o direito à autodeterminação deveria ser tratado com base no princípio da não-intervenção, devendo ser analisado o seu escopo e conteúdo como condição para aferir quando intervenções num Estado são permitidas. Assim, em questões humanitárias, por exemplo, seria admitida uma intervenção internacional quando o controle interno do Estado estivesse em falta ${ }^{67}$.

É preciso pontuar também o caráter erga omnes do princípio da autodeterminação dos povos, uma vez que é oponível a todos e deve ser respeitado pelos Estados.

Por fim, Matthew Saul sustenta que a autodeterminação tem caráter de norma jus cogen. Ou seja, caráter de norma peremptória, aceita e reconhecida pela comunidade internacional de Estados, que não permite derrogação, só podendo ser modificada por uma norma geral internacional posterior, dotada de mesmo caráter ${ }^{68}$.

Marco Antonio Barbosa, por sua vez, defende que a autodeterminação dos povos "trata-se de norma imperativa de direito internacional geral e que não pode ser derrogada por nenhuma outra" 69 , ou seja, norma jus cogen.

No entanto, ao problematizar de forma mais profunda a questão, Matthew Saul levanta algumas abordagens sobre o caráter jus cogen da autodeterminação, tendo em vista que, como o conteúdo desse princípio não foi bem determinado, os acadêmicos do assunto divergem a esse respeito. Não entraremos nessa discussão, tendo em vista que não é objeto do presente trabalho ${ }^{70}$. Ademais, muitas incertezas pairam ainda sobre o próprio conceito e conteúdo do jus cogen, que são objeto de vários debates entre teóricos do assunto ${ }^{71}$.

A respeito de quais seriam essas normas imperativas e inderrogáveis, Salem Nasser reuniu os exemplos mais comumente citados de jus cogens, tanto nos trabalhos da Comissão de Direito Internacional, quanto nos escritos dos doutrinadores:

[...] o princípio pacta sunt servanda; a proibição do uso ou da ameaça do uso da força, a proibição dos atos que infrinjam a soberania e a

\footnotetext{
66 SAUL, Matthew. The Normative Status of Self-Determination in International Law: A Formula for Uncertainty in the Scope and Content of the Right? Disponivel em: <http://papers.ssrn.com/sol3/papers.cfm?abstract_id=1881679>. Acesso em: 10 out. 2014, p. 17.

67 lbidem, p. 17.

68 Ibidem, p. 20. Definição encontrada também no art. 53 da Convenção de Viena de 1969.

69 BARBOSA, Marco Antonio. Autodeterminação: direito à diferença. São Paulo: Plêiade/Fapesp, 2001, p. 318.

70 Nesse aspecto, sugerimos a leitura do artigo de Matthew Saul para um aprofundamento no debate. Cf. SAUL, Matthew. The Normative Status of Self-Determination in International Law: A Formula for Uncertainty in the Scope and Content of the Right? Disponivel em: <http://papers.ssrn.com/sol3/papers.cfm?abstract_id=1881679>. Acesso em: 10 out. 2014.

71 A esse respeito sugerimos a leitura de Salem Nasser. Cf. NASSER, Salem Hikmat. Jus Cogens: ainda esse desconhecido. In: Revista Direito GV, São Paulo, v. 1, n. 2, p. 161-178. Jun./Dez. 2005.
} 
igualdade dos Estados; o princípio da autodeterminação dos povos; o princípio da soberania sobre os recursos naturais; a proibição do tráfico de seres humanos; a proibição da pirataria; a proibição do genocídio; a proibição dos atos qualificados como crimes contra a humanidade; os princípios do direito humanitário codificados nas Quatro Convenções de Genebra, princípios fundamentais dos direitos humanos e do direito do meio ambiente ${ }^{72}$. (Grifo nosso)

O autor destaca a importância dessas normas para o ordenamento jurídico internacional, característica que têm em comum. "De resto, é possível intuir que elas possam indicar naturezas diversas para o jus cogens, que elas possam produzir efeitos diversos, e que possa haver consequências diversas conectadas à violação de umas e de outras"73.

Podemos então perceber que o princípio da autodeterminação dos povos encontrase no mesmo patamar, hierarquicamente falando, que as demais normas de direitos humanos, dada a importância que essas normas possuem no cenário internacional.

Passamos então a delinear os limites do princípio da autodeterminação dos povos, visto sob a perspectiva de que é um direito humano, oponível erga omnes, dotado de caráter jus cogen, mas que precisa ser restringido para uma adequada ponderação com os direitos humanos das mulheres.

\section{RESTRIÇÕES AO PRINCÍPIO DA AUTODETERMINAÇÃO DOS POVOS}

Partindo da ideia de que o princípio da autodeterminação dos povos é um direito humano, é preciso recorrer a noções da teoria geral dos direitos fundamentais para lograr êxito em tratar de suas restrições. Essa tarefa não é nada fácil, principalmente porque uma abordagem exaustiva dessa teoria ultrapassaria os limites e objetivos do presente trabalho.

Entretanto, não podemos deixar de abordar as bases dessa teoria, partindo de uma breve análise do aspecto morfológico das normas que veiculam tais direitos. Antes, devese esclarecer que muitos autores fazem uma distinção entre a noção de direitos humanos e direitos fundamentais, na qual aqueles seriam mais amplos do que estes. Entretanto, optamos aqui por considerar estes termos sinônimos, como preferem George Sarmento, Stela Valéria Cavalcanti ${ }^{74}$.

Segundo Jane Reis, direito fundamental é uma categoria jurídica complexa, que pode ser analisada a partir de múltiplos enfoques ${ }^{75}$. No que se refere ao problema da possibilidade de estes serem objeto de restrições, a qualificação de tais normas como regras ou princípios tem importância primordial.

Robert Alexy, em sua teoria dos direitos fundamentais, aborda a distinção entre regras e princípios, alegando que essa distinção não é nova, mas a seu respeito há uma

72 NASSER, Salem Hikmat. Jus Cogens: ainda esse desconhecido. In: Revista Direito GV, São Paulo, v. 1, n. 2, p. 161-178. Jun./Dez. 2005, p. 165.

${ }^{73}$ NASSER, Salem Hikmat. Jus Cogens: ainda esse desconhecido. In: Revista Direito GV, São Paulo, v. 1, n. 2, p. 161-178. Jun./Dez. 2005, p. 166.

${ }^{74}$ CAVALCANTI, Stela Valéria Soares de Farias. Violência Doméstica Contra a Mulher no Brasil. $4^{a}$ Ed. Salvador: Jus Podivm, 2012, p. 94-95.

${ }^{75}$ PEREIRA, Jane Reis Gonçalves. Interpretação Constitucional e Direitos Fundamentais: uma contribuição ao estudo das restrições aos direitos fundamentais na perspectiva da teoria dos princípios. Rio de Janeiro: Renovar, 2006, p. 75. 
falta de clareza e polêmica ${ }^{76}$. Assim, reúne regras e princípios sob o conceito de norma, porque ambos dizem o que deve ser.

Existem vários critérios para se distinguir regras de princípios, mas o ponto decisivo nessa distinção apontado por Alexy é que os "princípios são normas que ordenam que algo seja realizado na maior medida possível dentro das possibilidades jurídicas e fáticas existentes" 77 , são assim "mandamentos de otimização". Já as regras são normas que são sempre satisfeitas ou não satisfeitas ${ }^{78}$.

Assim, no tocante aos direitos fundamentais, partindo-se da distinção entre regras e princípios, estes podem ser abordados de três formas. Consoante Jane Reis:

Primeiramente, há quem sustente que todos os direitos fundamentais são tutelados por normas que ostentam a natureza de regras. De outro $l a d o$, algumas vertentes situam-se no extremo oposto, entendendo que as normas de direito fundamental são sempre princípios. Conciliando as duas noções, o modelo conhecido como teoria dos princípios defende que os catálogos de direitos fundamentais têm conteúdos mistos, compreendendo tanto normas-regra como normas-princípio ${ }^{79}$.

A teoria dos princípios atualmente é o modelo mais adequado para orientar a interpretação do sistema de direitos fundamentais. Esse conjunto misto é adotado na maioria das Constituições contemporâneas ${ }^{80}$.

Tal modelo concilia a flexibilidade que é inerente aos princípios com a taxatividade das regras, uma vez que não só os catálogos de direitos fundamentais contêm regras e princípios, mas uma mesma disposição pode expressar as duas categorias normativas ${ }^{81}$.

Interessante destacar que no debate sobre se a autodeterminação dos povos seria uma regra ou um princípio, Mathew Saul alega que parece mais acertado defender que a autodeterminação é tanto regra quanto princípio, pois serve como um "princípio guardachuva" que abarca uma coleção de regras específicas ${ }^{82}$.

Segundo Jane Reis, há uma estreita conexão entre a adoção de um modelo de regras ou princípios e a metodologia empregada para solucionar problemas de direitos fundamentais, ligados à admissibilidade de restrições a esses direitos e o emprego da ponderação ${ }^{83}$. Isso porque, entender tais direitos como regras leva a concebê-los como comandos insuscetíveis de restrição, enquanto o modelo de princípios, conduz à concepção de que os direitos fundamentais são passíveis de restrição ${ }^{84}$.

\footnotetext{
${ }^{76}$ ALEXY, Robert. Teoria dos Direitos Fundamentais. $2^{a}$ ed. São Paulo: Malheiros, 2011, p. 86-87.

77 Ibidem, p. 90.

78 Ibidem, 2011, p. 91.

79 PEREIRA, Jane Reis Gonçalves. Interpretação Constitucional e Direitos Fundamentais: uma contribuição ao estudo das restrições aos direitos fundamentais na perspectiva da teoria dos princípios. Rio de Janeiro: Renovar, 2006, p. 122.

80 Ibidem, p. 126.

81 Ibidem, p. 125.

82 SAUL, Matthew. The Normative Status of Self-Determination in International Law: A Formula for Uncertainty in the Scope and Content of the Right? Disponivel em: <http://papers.ssrn.com/sol3/papers.cfm?abstract_id=1881679>. Acesso em: 10 out. 2014, p. 13.

83 PEREIRA, Jane Reis Gonçalves. Interpretação Constitucional e Direitos Fundamentais: uma contribuição ao estudo das restrições aos direitos fundamentais na perspectiva da teoria dos princípios. Rio de Janeiro: Renovar, 2006, p. 127.

84 Ibidem, p. 127.
} 
Os direitos fundamentais não são absolutos, tendo em vista que a ampla gama de direitos assegurada induz à necessidade de harmonizá-los entre si e com outros valores e bens protegidos pela ordem jurídica.

A universalidade dos direitos torna indispensável sua limitação, sob pena de ineficácia, pelo que precisam ser harmonizados. Em situações em que temos direitos antagônicos, é imprescindível promover uma acomodação hermenêutica, na qual um deles deve ceder total ou parcialmente em favor do outro.

As limitações a direitos podem ser impostas de várias formas, podendo decorrer de intervenções legislativas, do próprio perfil traçado na Constituição ou in concreto, por meio da ponderação de interesses feita pelo Judiciário ${ }^{85}$. Entretanto, apesar de aceita a ideia de que os direitos fundamentais são relativos, problemática é a noção dos limites a serem impostos.

Alexy defende a existência de duas teorias acerca das restrições a direitos fundamentais. A primeira delas é a teoria externa, que concebe a ideia de que existem duas coisas distintas - o direito e a sua restrição - pois o direito existe em si, não restringido, e após a restrição resta o direito restringido ${ }^{86}$. Nessa teoria, a relação entre o direito e a sua restrição, "é criada somente a partir da exigência, externa ao direito em si, de conciliar os direitos de diversos indivíduos, bem como direitos individuais e interesses coletivos" $" 87$.

A segunda teoria abordada por Alexy é a teoria interna, segundo a qual não existiriam o direito e a sua restrição, mas apenas o direito com um determinado conteúdo, onde o conceito de restrição seria substituído pelo conceito de limite, ligado ao conteúdo do direito ${ }^{88}$. Essa teoria refuta a ideia da existência de conflitos entre os direitos, e consequentemente da ponderação.

$\mathrm{Na}$ maior parte das vezes, o resultado final a que se chega adotando uma ou outra teoria não é diferente, pois o debate entre elas refere-se essencialmente ao modo de fundamentar as decisões judiciais ${ }^{89}$. Deve-se então questionar qual a mais adequada para explicar os problemas envolvendo direitos fundamentais.

Assim, a teoria externa parece ser a mais adequada uma vez que os direitos fundamentais não estão tutelados por normas com significado inequívoco, e não há como determinar se certas condutas estão ou não compreendidas em sua esfera de proteção. Nessas situações, o raciocínio ponderativo sopesa as razões em favor do direito e as que defendem sua restrição, não podendo ser dispensado ${ }^{90}$.

Nesse sentido, a teoria externa é correlativa do modelo de ponderação e da teoria dos princípios. Admite que é possível que os direitos sejam restringidos em decorrência de razões antagônicas que em determinadas situações, assumam maior peso ${ }^{91}$.

Tendo em vista a vasta gama de direitos fundamentais positivados, sua tutela implica necessariamente que se restrinjam reciprocamente. Há assim uma autorização

\footnotetext{
85 PEREIRA, Jane Reis Gonçalves. Interpretação Constitucional e Direitos Fundamentais: uma contribuição ao estudo das restrições aos direitos fundamentais na perspectiva da teoria dos princípios. Rio de Janeiro: Renovar, 2006, p. 137.

${ }^{86}$ ALEXY, Robert. Teoria dos Direitos Fundamentais. $2^{\mathrm{a}}$ ed. São Paulo: Malheiros, 2011, p. 277.

87 Ibidem, p. 277.

88 Ibidem, p. 278.

89 PEREIRA, Jane Reis Gonçalves. Interpretação Constitucional e Direitos Fundamentais: uma contribuição ao estudo das restrições aos direitos fundamentais na perspectiva da teoria dos princípios. Rio de Janeiro: Renovar, 2006, p. 167.

90 Ibidem, p. 179.

91 Ibidem, p. 151.
} 
implícita ao legislador e ao Judiciário para restringi-los, entretanto, toda e qualquer restrição deve observar requisitos formais e materiais ${ }^{92}$.

Do ponto de vista formal, as restrições só poderão ser estabelecidas em lei, e, no caso da limitação hermenêutica, o órgão judiciário há de ser competente. No que se refere aos limites materiais, tanto os órgãos legislativos como os judiciários deverão observar o imperativo da proporcionalidade, engendrando uma interpretação coerente com o princípio da dignidade da pessoa humana ${ }^{93}$.

Nessa nossa reflexão acerca das restrições a direitos fundamentais, o método da ponderação nos parece o mais adequado ${ }^{94}$ para solucionar conflitos entre o princípio da autodeterminação dos povos e os direitos humanos das mulheres.

A ponderação é um dos métodos de interpretação constitucional, mas que não deflui de "um comando constitucional expresso, estando vinculado a uma determinada forma de entender o ordenamento jurídico, os direitos fundamentais e as relações entre a função judicial e a legislativa" 95 .

Pode ser definida como a técnica de decisão pela qual o operador jurídico, diante de bens e interesses juridicamente protegidos, mas inconciliáveis no caso concreto, realiza um sopesamento a fim de determinar qual dos direitos possui maior peso, devendo prevalecer como decisão para o caso concreto ${ }^{96}$.

Os conflitos de direitos fundamentais são espécies de antinomias normativas, ou seja, colisões de princípios. Tais conflitos, de um modo geral, ocorrem entre normas contemporâneas e de idêntica hierarquia no sistema de fontes; emergem em concreto, pois as normas que os consagram revelam-se compatíveis em abstrato; e são antinomias eventuais ${ }^{97}$.

A ponderação, como técnica de decisão, identifica-se com a aplicação do princípio da proporcionalidade, onde se colocam em equação os ônus e as vantagens que defluem da tutela total ou parcial de cada um dos bens jurídicos em conflito ${ }^{98}$.

Entretanto, como praticamente nada em direito está isento de controvérsias, o método da ponderação também sofre críticas. Temos que ter em mente que, apesar do juízo de ponderação ser vulnerável a considerações morais e acomodar certa dose de discricionariedade, não se trata de uma metodologia destituída de parâmetros racionais; bem como que, assim como outros meios de solução de problemas constitucionais, não se pode chegar definitivamente à "única resposta correta" 99 .

A vantagem da ponderação é a sua transparência, pois traz à baila as apreciações valorativas que são realizadas para se chegar à decisão. Pauta-se pelo princípio da

\footnotetext{
92 Ibidem, p. 214.

93 PEREIRA, Jane Reis Gonçalves. Interpretação Constitucional e Direitos Fundamentais: uma contribuição ao estudo das restrições aos direitos fundamentais na perspectiva da teoria dos princípios. Rio de Janeiro: Renovar, 2006, p. 214.

94 Destacamos aqui que a ponderação não é o único método de interpretação constitucional, como explica Jane Reis, existem outros, como a hierarquização e a categorização.

95 Ibidem, p. 215.

96 Ibidem, p. 221.

97 Ibidem, p. 224.

98 Ibidem, p. 266-267.

99 Ibidem, p. 272-273.
} 
proporcionalidade, cuja interpretação argumentativa determina de que modo o Judiciário deve implementar o sopesamento para fundamentar a solução final ${ }^{100}$.

Devemos ressaltar ainda que a atividade de limitar direitos humanos é, também, uma atividade limitada. Não se pode esquecer que as normas de direitos fundamentais ostentam caráter vinculante, sendo necessário estabelecer barreiras quando se trata da imposição de limitações a estas ${ }^{101}$. Não há um consenso sobre quais são os limites dos limites dos direitos fundamentais, mas a doutrina se encarregou de designar alguns como, por exemplo, a reserva de lei, o princípio do respeito ao conteúdo essencial dos direitos e também os princípios da razoabilidade e proporcionalidade.

O princípio da proporcionalidade é o critério que melhor se adequa à linha de raciocínio que estamos adotando, pois se traduz numa estrutura de pensamento consistente em avaliar a correlação entre os fins visados e os meios empregados nos atos do Poder Público.

Consoante os subprincípios da proporcionalidade, toda medida restritiva de direitos deve ter a aptidão de favorecer a implementação de um fim constitucionalmente legítimo; deve ser menos onerosa para os direitos, comparada a outras igualmente aptas; e o proveito obtido com a implementação da restrição deve ser menor que os sacrifícios que esta acarreta ${ }^{102}$.

Assim, tendo em vista que é perfeitamente possível restringir-se direitos fundamentais, principalmente em situações de conflito, sugerimos essa abordagem ao lidar com o princípio da autodeterminação dos povos e os direitos humanos das mulheres como direitos antagônicos em certos casos concretos. A técnica da ponderação pode ser empregada nesse sentido a fim de sopesar os direitos em conflito, devendo ser tutelado aquele de maior peso, enquanto que o de menor peso deve ceder total ou parcialmente em favor do outro.

Nesse sentido, vemos muitas vezes direitos imprescindíveis à dignidade da pessoa humana, como o direito à vida, o direito à integridade física e moral das mulheres sofrerem violações em diversos países e culturas espalhados pelo mundo. Por isso defendemos a necessidade de restringir o direito à autodeterminação dos povos, atendendo critérios de razoabilidade e proporcionalidade, para que a comunidade internacional possa agir no combate às violações de direitos humanos das mulheres.

\section{MEDIDAS NECESSÁRIAS PARA PROTEGER OS DIREITOS HUMANOS DAS MULHERES}

Ao longo do presente trabalho, pudemos perceber a importância central que os direitos humanos adquiriram internacionalmente. Vimos que, com o surgimento de uma nova ordem global, preocupada em "converter os direitos humanos em tema de legítimo interesse da comunidade internacional" ${ }^{103}$, rompe-se com a noção de soberania estatal

\footnotetext{
100 Ibidem, 2006, p. 279.

101 Ibidem, p. 297.

102 Aqui fazemos menção aos subprincípios da adequação, necessidade e proporcionalidade em sentido estrito, que não serão analisados detidamente. Cf. PEREIRA, Jane Reis Gonçalves. Interpretação Constitucional e Direitos Fundamentais: uma contribuição ao estudo das restrições aos direitos fundamentais na perspectiva da teoria dos princípios. Rio de Janeiro: Renovar, 2006, p. 312-313. 103 CAVALCANTI, Stela Valéria Soares de Farias. Violência Doméstica Contra a Mulher no Brasil. $4^{a}$ Ed. Salvador: Jus Podivm, 2012, p. 93.
} 
absoluta, "na medida em que são admitidas intervenções no plano nacional, em prol da proteção dos direitos humanos" ${ }^{104}$. Cria-se então a consciência de que há limites à liberdade e à autonomia dos Estados.

No intuito de relacionar o princípio da autodeterminação dos povos com os direitos humanos das mulheres, demonstramos que ambos estão no mesmo nível hierárquico, pois a autodeterminação também é um direito humano. Entretanto, no caso concreto esses direitos tendem a entrar em conflito, pois a forma como muitos povos determinam sua cultura discrimina as mulheres, violando assim seus direitos humanos mais básicos.

Nesse sentido, tendo em mente que a liberdade e a autonomia dos Estados possuem limites, defendemos a possibilidade de restrição do direito à autodeterminação dos povos, que por meio de um método ponderativo deve ser sopesado com outros direitos em conflito, no caso os direitos humanos das mulheres, cedendo espaço em favor dos direitos de maior peso, a depender do caso concreto.

O Estado tem responsabilidade primária pela proteção dos direitos humanos, ao passo que a comunidade internacional tem a responsabilidade secundária. O Direito Internacional dos Direitos Humanos "situa-se como direito subsidiário e suplementar ao direito nacional, no sentido de permitir sejam superadas suas omissões e deficiências" 105 .

No caso das violações de direitos humanos das mulheres, o Direito Internacional possui um papel primordial, pois o maior problema é a tolerância da discriminação no plano interno, por ser reflexo da cultura patriarcal. Assim, os Estados costumam ser negligentes e omissos, e essas violações tendem a se perpetuar sem uma responsabilização a nível internacional.

Portanto, temos que atentar para o fato de que o descumprimento das obrigações pactuadas e a consequente violação dos direitos humanos faz possível "a responsabilização do Estado no domínio internacional quando as instituições nacionais se mostram falhas ou omissas" ${ }^{106}$ na tarefa de protegê-los.

Várias medidas podem ser adotadas para a proteção dos direitos humanos, uma vez que foram criados tribunais internacionais, mecanismos previstos em tratados de direitos humanos, órgãos regionais de proteção como a Comissão Interamericana e a Comissão Europeia ${ }^{107}$. Os próprios indivíduos foram elevados a sujeitos de direitos da ordem internacional, podendo exigir o respeito aos direitos do homem. Através de denúncias de indivíduos ou de outros Estados aos organismos internacionais, casos de violações serão investigados, podendo ser levados a Cortes Internacionais.

Partindo da noção de que o Estado é o primeiro garantidor dos direitos humanos, o próprio juiz nacional poderia efetuar o controle da conformidade de uma norma interna em respeito a uma norma internacional, mais especificamente quanto a conformidade da lei aos tratados internacionais em relação aos quais o Estado tenha consentido a se obrigar $^{108}$. Esse método é chamado controle de convencionalidade, noção nova na doutrina que pode ser tomada como um importante ponto de partida para a proteção dos

104 PIOVESAN, Flávia. Direitos Humanos e o Direito Constitucional Internacional. 19a ed. São Paulo: Saraiva, 2009, p. 118.

105 PIOVESAN, Flávia. Direitos Humanos e o Direito Constitucional Internacional. 19ª ed. São Paulo: Saraiva, 2009, p. 161.

106 Ibidem, p. 121.

107 MELLO. Celso D. de Albuquerque. Curso de Direito Internacional Público. Vol. 1. 15a ed. Renovar: Rio de Janeiro, 2004, p. 864.

${ }_{108}$ CAVALLO, Gonzalo Aguilar. El Control de Convencionalidad: Análisis em Derecho Comparado. In: Revista Direito GV. São Paulo, p. 721-754, vol. 9, jul-dez 2013, p. 721. 
direitos humanos, principalmente os direitos das mulheres que apesar de consagrados internacionalmente não guardam uma estreita correlação com as normas de direito interno de vários países.

O controle de convencionalidade é uma noção que segue as bases do controle de constitucionalidade. A obrigação deste controle, consoante Gonzalo Aguilar, pode encontrar sua fonte no direito internacional:

Primeiro, na impossibilidade de alegar impedimentos de direito interno para não cumprir as obrigações derivadas do direito internacional. Segundo, na obrigação do Estado de adequar sua ordem jurídica interna ao direito internacional. Terceiro, na obrigação do Estado de garantir o gozo dos direitos humanos consagrados nos instrumentos internacionais ${ }^{109}$.

Essa é uma noção nova, que aqui elencamos como exemplo de medida que pode ser tomada para a proteção dos direitos humanos das mulheres ${ }^{110}$.

Já vimos que os Estados têm a obrigação de respeitar e garantir os direitos humanos, e diante de violações ocorridas em seu território devem investigar e punir os responsáveis, a fim de que essas violações sejam reparadas. As falhas no cumprimento destes compromissos ensejam a responsabilidade internacional do Estado.

Celso D. de Albuquerque Mello cita o entendimento da Corte Interamericana de Direitos Humanos no caso Velasquez, em 1988, segundo a qual um ato atentatório aos direitos do homem acarreta a responsabilidade internacional do Estado ainda que não o tenha praticado diretamente, mas sim em razão da sua omissão para prevenir a violação ${ }^{111}$.

Nesse sentido, o Estado violador teria em primeiro lugar a obrigação de cessar o ato ilícito e posteriormente de reparar os prejuízos causados, onde inúmeras decisões têm determinado ainda o pagamento de indenização ${ }^{112}$.

A obrigação de respeitar os direitos humanos é uma obrigação erga omnes e os Estados possuem esse dever mesmo que não tenham para isso um compromisso jurídico, como afirmou a própria Corte Internacional de Justiça, em 1986, no caso Nicarágua vs. $\mathrm{EUA}^{113}$.

Ressaltamos ainda que, tendo em vista que o princípio da autodeterminação dos povos não é absoluto, organismos internacionais devem fazer recomendações voltadas à legislação interna dos Estados violadores de direitos humanos, para que o poder público se comprometa a editar leis que punam severamente as violações, e os responsáveis sejam investigados e processados adequadamente, pois a comunidade internacional reuniu direitos que considerou o mínimo necessário à promoção da dignidade humana, situados acima das particularidades culturais de cada povo.

Não estamos alheios ao fato de que a tese defendida no presente trabalho suscita críticas advindas da dicotomia entre universalismo e relativismo cultural. $\mathrm{O}$ elemento

109 CAVALLO, Gonzalo Aguilar. El Control de Convencionalidad: Análisis em Derecho Comparado. In: Revista Direito GV. São Paulo, p. 721-754, vol. 9, jul-dez 2013, p. 722. (Tradução livre)

110 No Brasil, Valério Mazzuoli foi o primeiro a escrever sobre o controle de convencionalidade. Cf. MAZZUOLI, Valério de Oliveira. Teoria Geral do Controle de Convencionalidade no Direito Brasileiro. Disponível em: <http://www2. senado.leg.br/bdsf/bitstream/handle/id/194897/000861730.pdf?sequence=3>. Acesso em: 23 out. 2014. 111 MELLO. Celso D. de Albuquerque. Curso de Direito Internacional Público. Vol. 1. 15 a ed. Renovar: Rio de Janeiro, 2004, p. 864.

112 Ibidem, p. 864.

113 Ibidem, p. 865. 
cultural foi aqui bastante destacado como sendo o maior problema enfrentado no respeito aos direitos humanos das mulheres, em virtude do patriarcalismo.

Nesse sentido, o relativismo cultural preceitua que devem ser respeitadas as diferenças culturais de cada povo, pois não existiria uma moral universal, já que a história do mundo é a história de uma pluralidade de culturas e a busca por uma universalidade parte de uma visão imperialista ${ }^{114}$. Os direitos humanos e sua ordem internacional de proteção, por sua vez, partem de uma noção universalista, na qual a dignidade humana é um valor intrínseco à própria condição humana, e "qualquer afronta ao chamado 'mínimo ético irredutível' que comprometa a dignidade humana, ainda que em nome da cultura, importará em violação a direitos humanos"115.

A Declaração de Viena de 1993 , em seu $\S 5^{\circ}$, preceitua a solução deste debate defendida por vários doutrinadores da atualidade:

5. Todos os Direitos Humanos são universais, indivisíveis, interdependentes e inter-relacionados. A comunidade internacional deve considerar os Direitos Humanos, globalmente, de forma justa e equitativa, no mesmo pé e com igual ênfase. Embora se deva ter sempre presente o significado das especificidades nacionais e regionais e os diversos antecedentes históricos, culturais e religiosos, compete aos Estados, independentemente dos seus sistemas políticos, econômicos e culturais, promover e proteger todos os Direitos Humanos e liberdades fundamentais ${ }^{116}$.

Assim, há a necessidade de superar esse debate sobre universalismo e relativismo cultural, entendendo que a universalidade é enriquecida pela diversidade cultural, que jamais pode ser invocada para justificar violações aos direitos humanos ${ }^{117}$.

Intervenções nos Estados que se manifestem através do uso da força também não devem ser incentivadas, posto que a criação da ONU se deu justamente para promover a paz e a segurança internacionais, partindo do pressuposto de que todos os Estados são iguais $^{118}$.

Nesse sentido inclusive, a "intervenção unilateral configura violação da integridade territorial e da independência política dos Estados" ${ }^{119}$. A maior crítica nesse sentido é a realização dessas intervenções sob o pretexto de proteger os direitos humanos quando na verdade ocultam interesses pessoais do Estado interventor. Alguns autores salientam ainda que as intervenções são feitas pelas grandes potências nos países subdesenvolvidos, perpetuando a desigualdade que existe entre os Estados.

As únicas hipóteses ainda previstas no Direito Internacional para o uso da força são no caso de legítima defesa, ou quando autorizada pelo Conselho de Segurança da ONU. Nesse último caso, o uso da força se daria diante da ameaça da paz e da segurança internacionais.

114 PIOVESAN, Flávia. Direitos Humanos e o Direito Constitucional Internacional. 19a ed. São Paulo: Saraiva, 2009 , p. 152.

115 PIOVESAN, Flávia. Direitos Humanos e o Direito Constitucional Internacional. 19a ed. São Paulo: Saraiva, 2009, p. 153.

116 CONFERÊNCIA de Direitos Humanos - Viena 1993. Disponível em: <http://www.dhnet.org.br/direitos/anthist/viena/viena.html>. Acesso em: 15 out. 2014.

117 PIOVESAN, Flávia. Direitos Humanos e o Direito Constitucional Internacional. 19a ed. São Paulo: Saraiva, 2009, p. 154-156.

118 AMARAL JÚNIOR, Alberto do. Curso de Direito Internacional Público. 4ª ed. São Paulo: Atlas, 2013, p. 219.

119 Ibidem, p. 220. 
Não se deve utilizar a força para privar os povos de seu direito de independência e autodeterminação. Por outro lado, atualmente a manutenção da paz no âmbito das relações internacionais requer o fim das violações dos direitos humanos, cuja magnitude provoque reação capaz de afetar a estabilidade existente ${ }^{120}$.

Assim, a defesa que fazemos da necessidade de restringir-se o princípio da autodeterminação dos povos obedece aos princípios da razoabilidade $\mathrm{e}$ proporcionalidade, para que não sejam cometidos abusos, devendo acontecer em situações de grave violação dos direitos humanos das mulheres, como ocorre nas omissões estatais diante dos casos de estupro, mutilação genital, tráfico para fins de exploração sexual, violência doméstica, ataques de ácido, entre outros exemplos que comprometem sobremaneira a possibilidade de uma vida digna de milhares de mulheres ao redor do mundo.

\section{CONCLUSÃO}

No decorrer de todo o trabalho, foi possível expor nossa preocupação com as constantes violações de direitos humanos das mulheres, uma vez que, apesar da conquista da igualdade de gênero e da positivação de uma série de direitos nos instrumentos internacionais, as mulheres continuam sendo vítimas de graves violações.

Através dos argumentos expostos, conclui-se que é possível o princípio da autodeterminação dos povos sofrer restrições para que possa ser harmonizado com a proteção dos direitos humanos das mulheres.

Como visto os conflitos de direitos fundamentais emergem em concreto, pois as normas que os consagram revelam-se compatíveis em abstrato. $O$ direito à autodeterminação dos povos e os direitos humanos das mulheres estão assim, num mesmo nível hierárquico, e são igualmente importantes. Entretanto, no caso concreto estes direitos tendem a entrar em conflito, pelo que é necessário recorrer ao método da ponderação, que nos parece o mais adequado para solucionar tais conflitos.

Nesse sentido, a comunidade internacional exerce atualmente um papel fundamental para coibir as práticas de violações dos direitos humanos das mulheres. Entretanto, muito ainda deve ser feito, visto que a cultura e o direito à autonomia interna servem de obstáculo para justificar violações de direitos humanos. Não se defende aqui o fim das particularidades culturais de cada povo, posto que todos os povos são sem dúvida titulares desse direito. Porém, a universalidade é enriquecida pela diversidade cultural, que jamais pode ser invocada para justificar violações aos direitos humanos.

Assim, deve-se fortalecer a noção de que os Estados são os principais garantidores dos direitos humanos, vinculados pela própria sistemática internacional de proteção. Devem procurar se alinhar internamente para cumprir o que foi positivado na ordem externa, obedecendo as recomendações dos organismos internacionais, alterando a legislação interna para melhor proteger os direitos humanos e combater as violações. Portanto, em caso de descumprimento, a comunidade internacional deve agir, de forma que o Estado violador seja responsabilizado.

120 Ibidem, p. 222. 


\section{REFERÊNCIAS BIBLIOGRÁFICAS}

ALEXY, Robert. Teoria dos Direitos Fundamentais. $2^{\mathrm{a}}$ ed. São Paulo: Malheiros, 2011. AMARAL JÚNIOR, Alberto do. Curso de Direito Internacional Público. $4^{\mathrm{a}}$ ed. São Paulo: Atlas, 2013.

BARBOSA, Marco Antonio. Autodeterminação: direito à diferença. São Paulo: Plêiade/Fapesp, 2001.

BRASIL, Decreto ${ }^{\circ} 19.841$, de 22 de outubro de 1945. Promulga a Carta das Nações Unidas. Disponível em: <http://www.planalto.gov.br/ccivil_03/decreto/19301949/d19841.htm>. Acesso em: 02 set. 2014.

BRASIL, Decreto n ${ }^{\circ} 591$, de 6 de julho de 1992. Promulga o Pacto Internacional sobre os Direitos Econômicos, Sociais e Culturais. Disponível em: <http://www.planalto.gov.br/ccivil_03/decreto/1990-1994/D0591.htm>. Acesso em: 01 set. 2014.

BRASIL, Decreto ${ }^{\circ}$ 592, de 6 de julho de 1992. Promulga o Pacto Internacional sobre Direitos Civis e Políticos. Disponível em: <http://www.planalto.gov.br/ccivil_03/decreto/1990-1994/D0592.htm>. Acesso em: 01 out. 2014.

BRASIL, Decreto n ${ }^{\circ} 4.377$, de 13 de setembro de 2002. Promulga a Convenção sobre a Eliminação de Todas as Formas de Discriminação contra a Mulher. Disponível em: http://www.planalto.gov.br/ccivil_03/decreto/2002/D4377.htm>. Acesso em: 06 ago. 2014.

BRASIL, Decreto ${ }^{\circ}$ 7.030, de 14 de dezembro de 2009. Promulga a Convenção de Viena sobre o Direito dos Tratados. Disponível em: <http://www.planalto.gov.br/ccivil_03/_Ato2007-2010/2009/Decreto/D7030.htm>. Acesso em: 15 set. 2014.

BROWLIE, Ian. Princípios de Direito Internacional Público. Lisboa: Fundação Calouste Gulbekian, 1997.

CAVALCANTI, Stela Valéria Soares de Farias. Violência Doméstica Contra a Mulher no Brasil. $4^{\text {a }}$ Ed. Salvador: Jus Podivm, 2012.

CAVALLO, Gonzalo Aguilar. El Control de Convencionalidad: Análisis em Derecho Comparado. In: Revista Direito GV. São Paulo, p. 721-754, vol. 9, jul-dez 2013.

CONFERÊNCIA de Direitos Humanos - Viena 1993. Disponível em: <http://www.dhnet.org.br/direitos/anthist/viena/viena.html>. Acesso em: 15 out. 2014.

DESCOLONIZAÇÃO: ONU festeja os 50 anos da Declaração sobre a Concessão de Independência. Disponível em: $<$ http://www.unric.org/pt/actualidade/30115descolonizacao-onu-festeja-os-50-anos-da-declaracao-sobre-a-concessao-deindependencia>. Acesso em: 02 set. 2014.

HERMANN, Breno. Soberania, não intervenção e não indiferença: reflexões sobre o discurso diplomático brasileiro. Brasília: Fundação Alexandre de Gusmão, 2011.

MARCHIONI, Alessandra. O "Princípio da Autodeterminação dos povos" no Direito Internacional e o Contraponto Constitucional do "Princípio do Indigenato". In: Pacto Internacional dos Direitos Econômicos, Sociais e Culturais: da previsão normativa à efetividade no Brasil. Rio de Janeiro: Lumen Juris, 2014.

MAZZUOLI, Valério de Oliveira; RIBEIRO, Maria de Fátima (coords.). Direito Internacional dos Direitos Humanos: Estudos em Homenagem à Prof ${ }^{\text {a }}$ Flávia Piovesan. Curitiba: Juruá, 2006 
MELlO. Celso D. de Albuquerque. Curso de Direito Internacional Público. Vol. 1. $15^{\text {a }}$ ed. Renovar: Rio de Janeiro, 2004.

NASSER, Salem Hikmat. Jus Cogens: ainda esse desconhecido. In: Revista Direito GV, São Paulo, v. 1, n. 2, p. 161-178. Jun./Dez. 2005.

ONU. UNite Survivor Stories. Vídeo da campanha para o fim da violência contra a mulher. Disponível em: <http://www.un.org/es/women/endviolence/>. Acesso em: 01 out. 2014.

PEREIRA, Jane Reis Gonçalves. Interpretação Constitucional e Direitos Fundamentais: uma contribuição ao estudo das restrições aos direitos fundamentais na perspectiva da teoria dos princípios. Rio de Janeiro: Renovar, 2006.

PIOVESAN, Flávia. Direitos Humanos e o Direito Constitucional Internacional. $19^{\mathrm{a}}$ ed. São Paulo: Saraiva, 2009.

REZEK, Francisco. Direito Internacional Público. 13a ed. São Paulo: Saraiva, 2011.

SARMENTO, George. Pontes de Miranda e a Teoria dos Direitos Fundamentais. Disponível em: <http://www.georgesarmento.com.br/wpcontent/uploads/2011/02/Pontes-de-Miranda-e-a-teoria-dos-direitosfundamentais2.pdf >. Acesso em: 15 out. 2014.

SAUL, Matthew. The Normative Status of Self-Determination in International Law: A Formula for Uncertainty in the Scope and Content of the Right? Disponível em: $<$ http://papers.ssrn.com/sol3/papers.cfm?abstract_id=1881679>. Acesso em: 10 out. 2014.

TAIAR, Rogério. Direito Internacional dos Direitos Humanos: Uma discussão sobre a relativização da soberania face à efetivação da proteção internacional dos direitos humanos. 2009. 321 f. Tese (Doutorado em Direitos Humanos) - Faculdade de Direito, Universidade de São Paulo, São Paulo. 2009.

THÜRER, Daniel. The Right of Self-determination of peoples. In: Law and State. Institute for Scientific Co-operation, v. 35, jan. 1987.

Recebido em: 05 de junho de 2016.

Aprovado em: 20 de julho de 2016. 